The main purpose of cleanrooms in health care centres is to prevent hospital infections or leakage of a highly infectious agent (the source of haemorrhagic fevers, SARS, etc.) into the ambient environment and subsequently possibly threatening other individuals.

Patients with haematological malignancies or after autologous or allogeneic haematopoietic stem cell transplantation (HSCT) rank among immunosuppressed individuals. Prolonged and deep neutropenia is considered a key risk factor of the occurrence of an exogenous infection. One of the possibilities of preventing an exogenous infection in these patients is to place them in a "cleanroom" for the crucial period of time. Cleanrooms are intensive care units with reverse isolation.

The final part of the general article below provides an overview of the technology and types of cleanrooms for immunosuppressed patients in compliance with the current recommendations and technical standards.

Key words: cleanroom, haemato-oncological patients, exogenous infection risk.

\section{The importance of cleanrooms for the treatment of haemato-oncological patients}

\author{
Ondřej Holý, Ivanka Matoušková
}

Department of Preventive Medicine, Faculty of Medicine and Dentistry, Palacký University Olomouc, Olomouc, Czech Republic

\section{Introduction}

Patients with haematological malignancies or after autologous or allogeneic hematopoietic stem cell transplantation (HSCT) rank among immunosuppressed individuals. Prolonged and deep neutropenia is considered a key risk factor of the occurrence of an exogenous infection. One of the possibilities of preventing an exogenous infection in these patients is to place them in a "cleanroom" for the crucial period of time. Cleanrooms are intensive care units with reverse isolation.

Due to their composition and especially due to the presence of microorganisms, some factors of the environment (air and water) represent dangerous, even life-threatening vehicles for these patients.

Chemically, the outside air is a mix of gasses of more or less stable composition. This applies, above all, to oxygen ( $21 \%$ by volume) and nitrogen ( $78 \%$ by volume). The remaining $1 \%$ is composed of carbon dioxide, hydrogen, and inert gasses. The first of the above is sometimes labelled as the indicator of the quality of the air in enclosed rooms. Airborne contaminants consist of inanimate particles forming aerosols (solid or liquid particles from $1 \mathrm{~nm}$ to $100 \mu \mathrm{m}$ large) and animate particles, i.e. microorganisms (bacteria, viruses, microscopic filamentous fungi, and yeast). These are termed bioaerosols. While the above applies to the air outside, in enclosed rooms the conditions are different, partly due to human activities. Certain curative and work procedures in health care centres require supply air be treated. The inside environment (aired room) must be maintained within specific, clearly predefined parameters that guarantee the most suitable microclimatic conditions. Air is treated by an air-conditioning device ensuring a controlled exchange, temperature, and relative humidity of the air in the particular room.

The requirements always ensue from the purpose of the device. The air of the inside environment is called interior air, polluted by the presence of people and operating technology. Substances released into the air are called contaminants. They have a negative impact on living organisms, buildings, and their equipment. In certain industries (automobile industry, microelectronics, precision mechanics, optics, and the pharmaceutical industry) or in health care centres, these interior rooms have the air cleanliness classes, stabilized temperature, and relative air humidity defined. They are labelled as follows: cleanrooms, cleanroom, clean desk, clean wall (clean ceiling), and clean worktop.

Cleanrooms are rooms defined predominantly by the number and size of the particles present in the air in uplift. In health care and pharmaceutical centres the rooms must also be protected from microorganisms.

The main purpose of cleanrooms in health care centres is to prevent hospital infections or leakage of a highly infectious agent (the source of hemorrhagic fevers, SARS, etc.) into the ambient environment and subsequently possibly threatening other individuals. 


\section{Cleanroom technology}

The beginnings of cleanroom technology date to the first half of the 20th century. Towards the end of the 1930s the HEPA (high performance particulate air) filter was developed, to be used in the Second World War for the gas masks of the Swiss army. The second condition is to ensure a one-way air flow in order to successfully control the particles it contains. A solution to this problem was published by Willis J. Whitfield [1] in 1962.

The cleanroom technology consists of a sequence of follow-up activities designed to control and minimize contaminants in the supply/exhaust air. It needs to meet the following requirements:

- protect the process or product from becoming damaged by contaminated air,

- protect persons from exposure to airborne contaminants that could endanger the persons' health, and

- protect the outside environment from harmful emissions generated in connection with the operation of the facility [1].

With airing and air conditioning, the filtration of the atmospheric air is the basic method of maintaining the required purity of the interior air of the given room. When creating cleanrooms, multilevel filtration forms an integral part of highly efficient filtration, where the requirements for high air purity ensue from the requirements of individual work procedures and of public health protection [2]. Three-level air filtration is recommended in order to meet the required air cleanliness class in cleanrooms in health care centres. A fine filter of class $\mathrm{F} 7$ is recommended as the pre-filter of the second and third filtration level. Highly efficient HEPA filters $\mathrm{H} 12-\mathrm{H} 13$ are recommended as the basic filters for all cleanrooms of class 100 to 100,000 pursuant to FED-STD-209E [3], which currently corresponds to class 5 pursuant to ČSN EN ISO 14644-1 [4]. They are highly efficient for all types of dust and aerosols including viruses. The three-level filtration must also be installed in discharge systems designed for hazardous aerosols (health care, biotechnology, nuclear power) [4]. For air cleanliness classes, see Table 1 .

Although the above represents only a small part of cleanroom technology, it is one of the basic prerequisites for creating the cleanrooms. Cleanrooms in health care centres are air-conditioned with the help of a sanitary air-conditioning unit working exclusively with fresh air. The supply air is humidified/dried and heated/cooled as required. At present, all required parameters of the supply air are carried out with the help of a computer program.

Another vehicle, in many cases even more hazardous than air, is water used for the standard hygiene of patients placed in a protective environment room. Although water coming from water pipes in health care centres meets the drinking water requirements of the applicable legislation, it is not suitable for these patients [5]. It can contain microbial infectious agents that are safe for healthy individuals but in immunosuppressed patients they may lead to even fatal infections [6, 7]. Apart from a number of Gram-negative non-fermenting bacteria, drinking water distribution systems in health care centres are often contaminated by various types of microscopic filamentous fungi [8-12]. Probably the greatest risk is the presence of Legionella in the hot water pipeline. Although hot water is produced from drinking water, it is termed "hot industrial water". Methods of efficient prevention of the occurrence of this bacterium are complex and costly [13].

Patients in isolation rooms usually use specially treated water for their personal hygiene. This water is a combination of mechanical and chemical treatment of drinking water designed to minimize the risk of the presence of any infectious agent. The occurrence of Legionella in the pipeline of treated water is minimized by having the water heated to more than $64^{\circ} \mathrm{C}$ and placing final filters on the shower and the faucet shoulder. Membrane pores in these filters are $0.22 \mu \mathrm{m}$ large, which prevents Legionella and other bacteria from entering.

Places recording increased humidity, e.g. drains, siphons, and sanitary facilities, are considered highly dangerous vehicles for the survival of usually conditioned pathogenic infectious agents. These as a rule involve Gram-negative nonfermenting bacteria that induce dangerous infections in immunosuppressed patients [6,14-18]. All these places must be paid increased attention and be regularly and efficiently decontaminated. The decontamination results need to be verified using growth media.

Table 1. Selected airborne particulate cleanliness classes for cleanrooms and clean zones (ISO 14644-1:1999 E)

\begin{tabular}{|c|c|c|c|c|c|c|}
\hline \multirow[t]{2}{*}{ ISO classification number $(\mathrm{N})$} & \multicolumn{6}{|c|}{$\begin{array}{l}\text { Maximum concentration limits (particles } / \mathrm{m}^{3} \text { of air) for particles equal } \\
\text { to and larger than the considered sizes shown below }\end{array}$} \\
\hline & $0.1 \mu \mathrm{m}$ & $0.2 \mu \mathrm{m}$ & $0.3 \mu \mathrm{m}$ & $0.5 \mu \mathrm{m}$ & $1 \mu \mathrm{m}$ & $5 \mu \mathrm{m}$ \\
\hline ISO Class 1 & 10 & 2 & & & & \\
\hline ISO Class 2 & 100 & 24 & 10 & 4 & & \\
\hline ISO Class 3 & 1000 & 237 & 102 & 35 & 8 & \\
\hline ISO Class 4 & 10000 & 2370 & 1020 & 352 & 83 & \\
\hline ISO Class 5 & 100000 & 23700 & 10200 & 3520 & 832 & 29 \\
\hline ISO Class 6 & 1000000 & 237000 & 102000 & 35200 & 8320 & 293 \\
\hline ISO Class 7 & & & & 352000 & 83200 & 2930 \\
\hline ISO Class 8 & & & & 3520000 & 832000 & 29300 \\
\hline ISO Class 9 & & & & 35200000 & 8320000 & 293000 \\
\hline
\end{tabular}




\section{Cleanrooms}

The origin of cleanrooms in health care centres dates to the time of Joseph Lister, who decontaminated the air in operating rooms by spraying Lysol solution.

The building technologies and materials of the twentieth century facilitated the construction of cleanrooms, which were supposed to solve two fundamental problems. Firstly they aim to protect the patient from an infectious agent (today also in other departments than just the operating room). Secondly, cleanrooms are built to prevent dangerous infectious agents from leaking from an infectious patient to the ambient environment. The latter was successfully solved by the American aerospace organization NASA, which was able to isolate astronauts in a moon laboratory after they returned from space, preventing the possible leakage of a hazardous infectious agent that could put humankind at risk.

Depending on the pressure ratios of the isolators' internal environment to the external one, cleanrooms are divided into two basic groups [19].

Airborne infection isolation rooms (All), designed to isolate patients with hazardous infectious diseases or if there is a suspicion of such a disease. The pressure of the surrounding air should foreclose leakage of the infectious agent. Contaminated air is drained through three-level filtration; the last filtration stage is ensured with HEPA or ULPA filters. These cleanrooms form part of the NASA moon laboratory. Cleanrooms of the above type are of great importance even today. Patients with the MRSA and SARS infections, pulmonary or laryngeal tuberculosis, and HIV positive patients with highresistance Mycobacterium tuberculosis strains are placed in airborne infection isolation rooms (Fig. 1) [20].

Health care and construction institutions in the USA, e.g. CDC and ASHRAE, issue recommendations concerning cleanrooms for patients treated for tuberculosis [21]. Figure 2 shows examples of All rooms with an anteroom and neutral anteroom.

Protective environment rooms aim at protecting the patient for the necessary period of time from a possible infectious agent from the outside, preventing an exogenous hospital-acquired infection. They are therefore sometimes referred to as "reverse isolation" (Fig. 3).
In the 1960s, plastic isolators with regulation of the pressure parameters were used by some surgical specialists, e.g. gynaecologists. The latter would deliver children into a sterile environment when the newborn was suspected to be suffering from a serious primary immunodeficiency. The isolator was a plastic "bubble" attached to a sterile pad. Through HEPA filters, sterile air flows into the interior environment, where a drain for the contaminated air is placed at the upper part of the equipment. A slight positive pressure against the ambient environment was maintained in the interior part of the designated area. Following the introduction of these isolators, surgeons recorded a lower number of postoperative infectious complications [6], and yet the isolators failed to become widely used. Basic technical parameters of both types of cleanrooms are listed in Table 2.

In health care centres, the majority of patients need to be protected from infectious agents. New treatment methods, e.g. cytostatic treatment and radiation therapy, require the patient to be protected from an exogenous infection for varying periods.

The implementation and incorporation of cleanrooms into health care centres is, above all, connected to haematooncological patients.

An isolator designed for clinical purposes was launched in the USA in 1957. This equipment was associated with the name Trexler [22]. In September 1964 the National Cancer Institute (Bethesda) began using an isolator, type "Life Iceland" produced by Matthews, for post-chemotherapy patients. It was a plastic isolator made from a translucent foil, into which air flew through HEPA filters that eliminated over $99.97 \%$ of particles larger than $0.3 \mu \mathrm{m}$. The air was changed twice to 16 times an hour, as required. Inside, the staff used special gloves placed in the wall. Two UV tubes were installed at the foot of the bed. The authors provided a precise description of the procedure for transporting a patient into the above isolator, including a strict decontamination regime, which was to prevent transfer of an infectious agent and the origin of an exogenous infection. The microbial contamination of the air (fall-out method) and the surfaces (swabs from hotspots) were continuously checked. Cultivation procedures focused on demonstrating aerobic

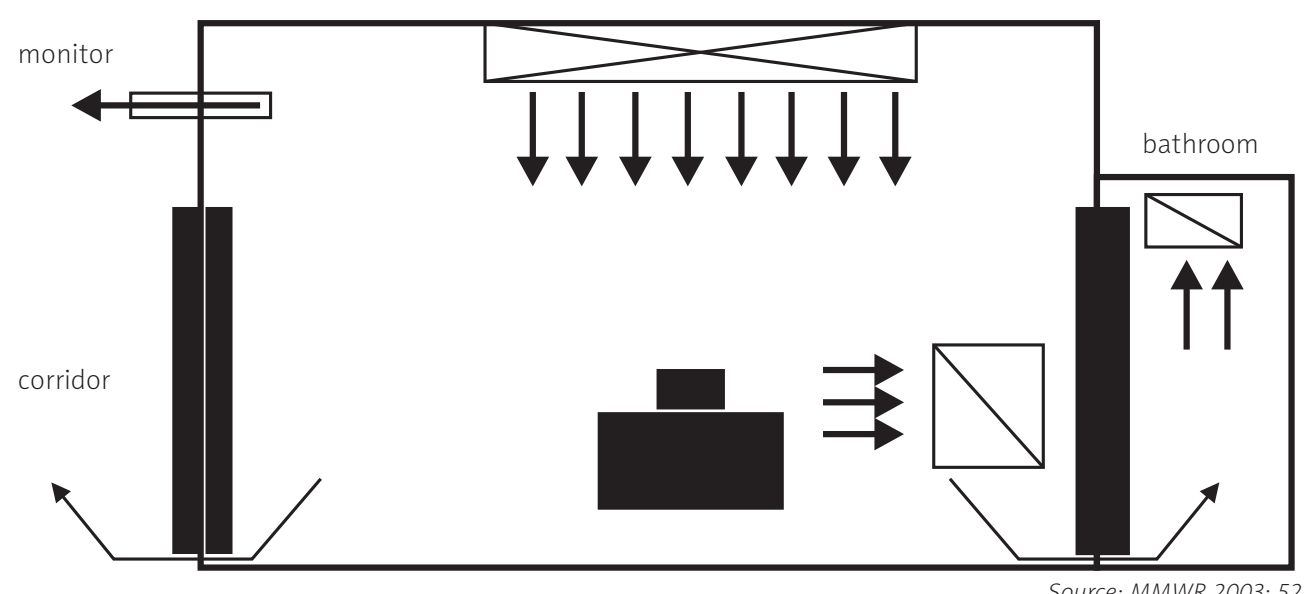

Fig. 1. Example of positive-pressure room control for protection from airborne environmental microbes 


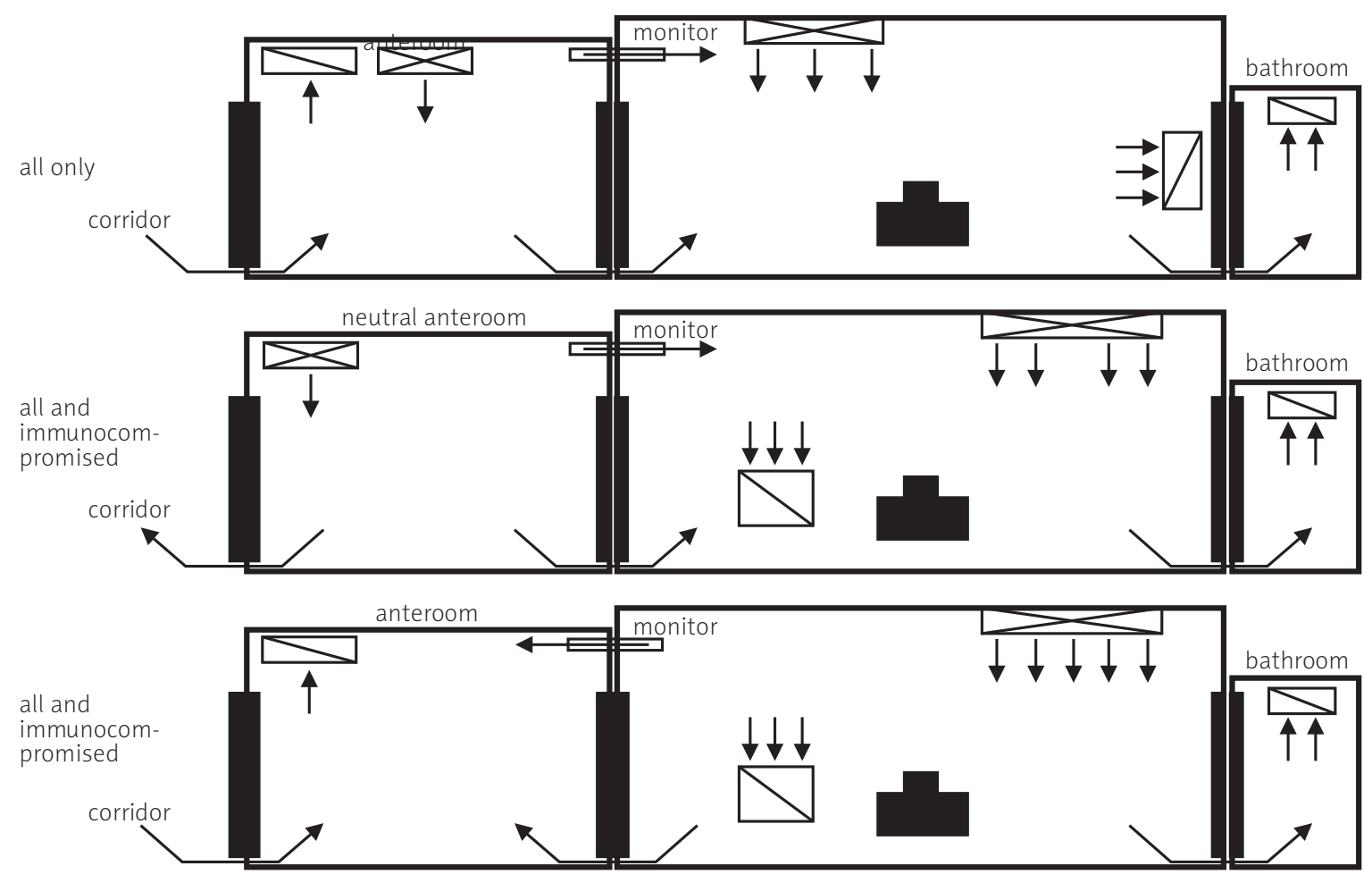

Fig. 2. Example of airborne infection isolation (AII) room with anteroom and neutral anteroom

Source: MMWR 2003; 52

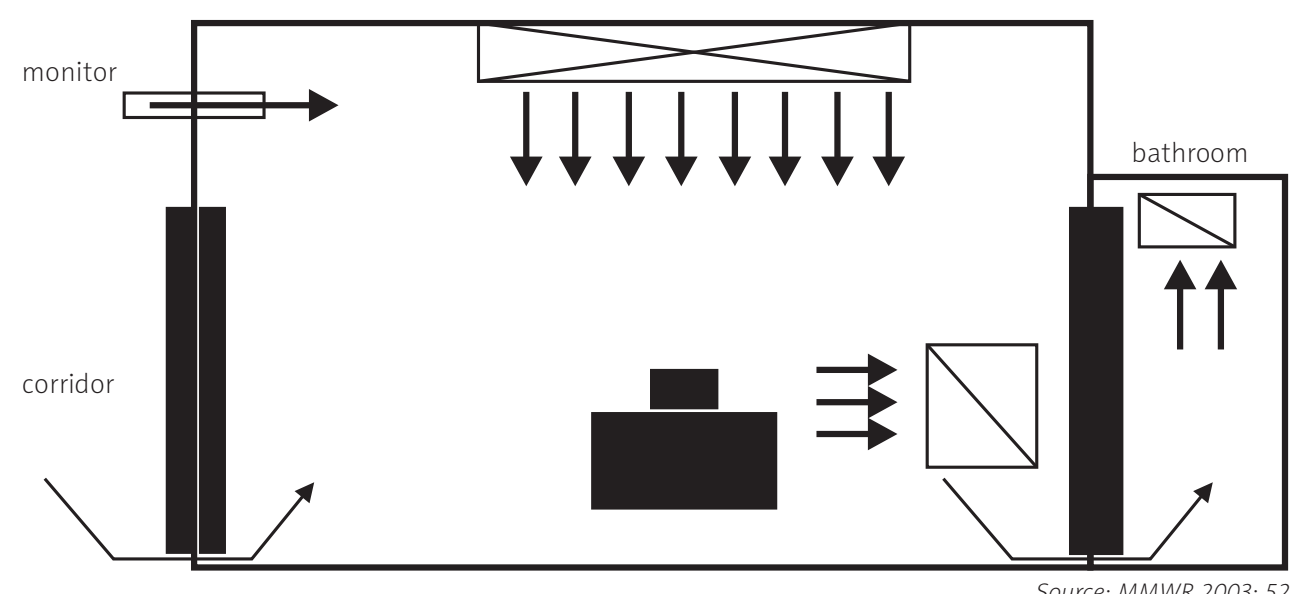

Fig. 3. Example of negative-pressure room control for airborne infection isolation (All)

bacteria stems and microscopic filamentous fungi. In terms of size, the facility was quite small. The treatment was problematic, generating undesirable mental states in patients [23].

In 1967 James and his colleagues [24] introduced a unit that was to decrease the possibility of an exogenous infection in patients after cytotoxic therapy. Two single rooms shared a sanitary facility and all these premises were supplied with treated air (20 air changes per hour; the filtration device retained particles larger than $0.5 \mu \mathrm{m}$, while the air temperature was $20^{\circ} \mathrm{C}$ and relative humidity $50 \%$ ). These units were surrounded with a "protective" gallery for communi- cation with the attending personnel. The authors stated that it was a compromise between the sterile room system and a single bed isolator.

In 1969 Schneider and his team published their three years' experience with the pathogen-free isolation unit [25]. Located in France, the unit contained five single rooms with facilities for the nurses and physicians, sterilisation, a kitchen for preparing sterile food, and a piping system with treated water sterilized by UV radiation. The supply air was treated by means of two-stage filtration and germicidal lamp radiation. All the above isolation units only supplied treated air and drained contaminated air. 
Table 2. Reference values for different types of cleanrooms

\begin{tabular}{|c|c|c|}
\hline & Protective environment room & Airborne infection isolation room \\
\hline Pressure relationships to adjacent areas & $P$ & $\mathrm{~N}$ \\
\hline Minimum air changes of outdoor air per hour & 2 & 2 \\
\hline Minimum total air changes per hour & 12 & 12 \\
\hline All air exhausted directly to outdoors & - & yes $(d)$ \\
\hline Air recirculated within room units & no & no \\
\hline Design temperature $\left[{ }^{\circ} \mathrm{C}\right]$ & $21.1-23.9$ & $21.1-23.9$ \\
\hline \multicolumn{3}{|l|}{ Airborne infection isolation room $(a, c, f)$} \\
\hline \multicolumn{3}{|c|}{$\begin{array}{l}\text { - The airborne infection isolation rooms described in this table are those that might be used for infectious patients in the average community hospital. } \\
\text { The rooms are negatively pressurized. Some isolation rooms may have a separate anteroom. }\end{array}$} \\
\hline \multicolumn{3}{|c|}{$\begin{array}{l}\text { - Protective environment rooms are those used for immunosuppressed patients. Such rooms are positively pressurized to protect the patient. Anterooms are } \\
\text { generally required and should be negatively pressurized with respect to the patient room. }\end{array}$} \\
\hline \multicolumn{3}{|c|}{ c-Difference in pressure between space and corridors shall be a minimum of $2.5 \mathrm{~Pa}$. } \\
\hline \multicolumn{3}{|c|}{$\begin{array}{l}d \text {-If exhausting the air from an airborne infection room to the outside is not practical, the air may be returned through HEPA filters to an air-handling system } \\
\text { exclusively serving the isolation room. }\end{array}$} \\
\hline \multicolumn{3}{|c|}{$\begin{array}{l}\text { - The protective environment airflow design specifications protect the patient from common environmental airborne infectious microbes (e.g. Aspergillus spo- } \\
\text { res). These special ventilation areas shall be designed to provide directed airflow from the cleanest patient area to less clean areas. These rooms shall be } \\
\text { protected with HEPA filters at } 99.97 \% \text { efficiency for } 0.3 \text { micron-sized particles in the supply airstream. These interrupting filters protect patient rooms from } \\
\text { maintenance-derived release of environmental microbes from the ventilation system components. Recirculation HEPA filters can be used to increase the equ- } \\
\text { ivalent room air exchanges. Constant volume airflow is required for consistent ventilation for the protected environment. If the design criteria indicate that } \\
\text { airborne infection isolation is necessary for protective environment patients, an anteroom should be provided. Rooms with reversible airflow provisions for } \\
\text { the purpose of switching between protective environment and airborne infection isolation functions are not acceptable. }\end{array}$} \\
\hline \multicolumn{3}{|c|}{$\begin{array}{l}\text { f- The infectious disease isolation room is to be used for isolating the airborne spread of infectious diseases such as measles, varicella or tuberculosis. The design } \\
\text { of airborne infection isolation (All) rooms should include the provision for normal patient care during periods not requiring isolation precautions. Supple- } \\
\text { mental recirculating devices may be used in the patient room to increase the equivalent room air exchanges; however, such recirculating devices do not pro- } \\
\text { vide the outside air requirements. Air may be recirculated within individual isolation rooms if HEPA filters are used. Rooms with reversible airflow provisions } \\
\text { for the purpose of switching between protective environment and All functions are not acceptable. }\end{array}$} \\
\hline
\end{tabular}

In 1969 Bodey and his colleagues [26] reported about a stable isolation unit equipped with a horizontal laminar flow of the treated air. An entire wall (behind the patient's head) was formed by HEPA filters with $99.97 \%$ efficiency for particles larger than $0.3 \mu \mathrm{m}$. The laminar flow of the intake air required a certain speed and a minimum amount of objects in the room to avoid a turbulent flow. The patient was not supposed to feel the exchange of the contaminated air as a draught. Here, too, a precise schedule of the patients' reception and stay in the facility was specified.

Czechoslovakia saw the launch of an improvised reverse isolation room for the treatment of patients suffering from haematological diseases in 1972 and the introduction of the laminar air flow system "Life Island Mark 12" produced by Matthews in 1974 [27]. At present, the reverse isolation units are being installed in the majority of Czech faculty hospitals (e.g. Faculty Hospital Motol, Faculty Hospital Brno, and Faculty Hospital Olomouc).

Different opinions on whether the isolator needs to be equipped with a HEPA filter appear in the professional literature. In his study from 2001, Dykewicz states that while the filter's importance in patients with autologous HSCT is lower or had not been demonstrated, patients with long-term neutropenia should be placed in a cleanroom equipped with a HEPA filter as it is one of the highly hazardous factors for the origin of hospital-acquired aspergillosis [29]. The increased risk of its emergence is related to the remodelling and reconstruction works carried out in health care centres. Any shifts in the old walling are always connected to the release of aspergillosis spores. The only protection against this hospital-acquired infection for immunosuppressed patients is a fully functioning three-stage air filtration concluded with HEPA filters [25].

In order to ensure smooth functioning of the entire HVAC device (a defect, reconstruction), the isolation rooms must have a back-up source of energy [31].

The technology of isolation rooms protecting critically ill patients from external infectious agents has existed for over fifty years. The cleanroom technology now provides optimal conditions of a clean environment, minimizing the risk of an exogenous infection. Protective environment rooms are today used especially for patients after autologous or allogeneic HSCT and peripheral stem cells, after high doses of chemotherapy, and for those suffering from a serious form of aplastic anaemia. Infections represent the main cause of morbidity and mortality of most haemato-oncological patients. The susceptibility to infection in these patients is closely related to their primary disease, chemotherapy, intravenous catheters, and special operations. $60 \%$ of febrile neutropenic patients report a bacterial infection. Bacterial infection prevails at the beginning of neutropenia, while infections induced by microscopic filamentous fungi usually emerge later. A viral infection may appear during the entire neutropenia period. Monitoring the risk of infection in 
these patients must also apply to the attending personnel and the whole environment of the relevant department.

Ideally, immunosuppressed patients would be placed in an entirely sterile environment, which can unfortunately be created only theoretically. This quality is violated every time a patient or attending personnel enter the room [28].

Patients themselves may represent the source of an infectious agent. Potential sources of infectious agents include the hair, skin, and mucous membranes of both the patients themselves (endogenous infection) and the attending personnel (exogenous infection). The risk of endogenous infection may be decreased by partial or total decontamination of the microbial population of the oral cavity, nasopharynx, the gastrointestinal tract, genitals, and skin. This problem is handled by clinical staff. Dust particles or food can serve as potential vectors [28]. The most prominent are Enterobacteriaceae, Pseudomonas aeruginosa, Staphylococcus aureus and Candida spp. [30].

Models that distinguish between infectious complications occurring during different post-transplantation phases have been put forth, based largely on a myeloablative paradigm in which phase I is the pre engraftment phase $(<15-45$ days after HSCT); phase II is the post-engraftment phase (30-100 days after HSCT); and phase III is the late phase (> 100 days after HSCT). During phase I, prolonged neutropenia and breaks in the mucocutaneous barrier result in substantial risk for bacteraemia and fungal infections involving Candida species and, as neutropenia continues, Aspergillus species. In addition, herpes simplex virus (HSV) reactivation occurs during this phase. During phase $I$, infections relate primarily to impaired cell-mediated immunity. The scope and impact of this defect are determined by the extent of GVHD and the immunosuppressive therapy for it. Herpesviruses, particularly CMV, are common infectious agents during this period. Other dominant pathogens during this phase include Pneumocystis jiroveci and Aspergillus species. During phase III, persons with chronic GVHD and recipients of alternatedonor allogeneic transplants remain most at risk for infection. Common pathogens include CMV, VZV and infections with encapsulated bacteria (for example, Streptococcus pneumoniae). The relative risk for these infections is approximately proportional to the severity of the patient's GVHD during phases II and III. For recipients of non myeloablative grafts, substantial differences may be observed during phase I, but the susceptibility to infections during phases II and III is largely similar, and driven primarily by the status of the underlying disease, a history of GVHD and/or the need for ongoing immunosuppression. The risk of disease from community-acquired respiratory viruses is elevated during all three phases; however, in phase III, the outpatient status of haematopoietic cell transplant recipients can complicate efforts to reduce exposure and provide timely intervention. Thus, the risk of infection is primarily determined by the time from transplant and the presence or absence of GVHD. Unfortunately, there is currently no definitive laboratory marker of immune reconstitution that can predict infectious risk that could be used to tailor infection prophylaxis [32].

\section{Infection prevention and control in health care facilities where hematopoietic stem cell transplantation recipients are treated}

It is necessary to meet the following requirements for efficient infection prevention and control in the cleanrooms for patients after HSCT:

- $\geq 12$ air exchanges per hour;

- central or point-of-use HEPA filters with $99.97 \%$ efficiency for removing particles $\geq 0.3 \mu \mathrm{m}$ in diameter;

- correct filtration is particularly critical in HSCT centres with ongoing construction and renovation;

- continuous pressure monitoring, especially while rooms are occupied;

- self-closing doors to maintain constant pressure differentials of anterooms should be used to ensure appropriate air balance;

- floor surfaces should be smooth, nonporous, and scrubbable to minimize dust levels;

- HSCT recipients should be placed in single-patient rooms, if possible. If the availability of single-patient rooms is limited, their use should be prioritized for the most severely immunosuppressed patients;

- hand hygiene includes both use of alcohol-based hand rubs and hand washing with soap (plain or antimicrobial) and water;

- equipment and devices should be cleaned, disinfected or sterilized, and maintained as directed by established guidelines;

- it is recommend that plants and dried or fresh flowers should not be allowed in hospital rooms during conditioning or after HSCT because Aspergillus species have been isolated from the soil of potted ornamental plants, the surface of dried flower arrangements, and fresh flowers.

The above recommendations were compiled according to Guidelines for Preventing Infectious Complications among Hematopoietic Cell Transplantation Recipients [33].

\section{Visitors and their influence on the patient's mental state}

The problem of attending personnel or visitors entering the cleanrooms remains a question. Patients are allowed visitors directly in the room only in exceptional cases, where their health and circumstances permit. Both visitors and the attending personnel are obliged to wear personal protective equipment and aids (mouthpieces, gloves, disposable lab coats, etc.) and disinfect their hands. These are precautions against spreading the infectious agent. The cleanroom units provide detailed instructions for visitors (if permitted) on how to minimize the risk of transferring an infectious agent. Some types of isolation rooms have galleries built around these rooms for visitors.

Persons with infections of the respiratory tract, flu-like illnesses, etc. are excluded from visiting. In some foreign countries, children are allowed to visit cleanrooms. They must be paid increased attention, however, as there is a possibility of the transfer of infectious diseases [28].

The role of visitors is indispensable - mainly psychologically. Patients may feel isolated and lonely and, likewise, they may believe (as they are placed in an isolation room) that 
the attending personnel visit them less often than the other rooms. If this is the case, the patient needs to be explained the necessity of the minimization of the possibility of transferring an infectious agent, and, above all, informed that a lower frequency of the personnel's entrance does not mean lower or impaired health care.

Within the current health care of immunosuppressed patients, cleanrooms hold a unique position in minimizing the risk of a hospital-acquired exogenous infection and in the recovery of these patients.

\section{Acknowledgments}

The project was supported by grant no. 801100021/39Surveillance of Infectious Complications in Hemato-Oncological Patients.

\section{References}

1. Schicht H. One-day course program "Essentials of Cleanroom Technology“. Exhibition Center Brno, Brno, Czech Republic 2006; 19-30.

2. Hemerka J. Filtrace atmosférického vzduchu I. http://www.tzbinfo.cz 2009

3. FED-STD-209E Cleanroom and Work Station Requirements, Controlled Environment. Aiborne Particulate Cleanliness in Cleanrooms and Clean Zones.

4. ČSN EN ISO 14644-1 (125301) - Čisté prostory a prríslušné řizené prostředí - Část 1: Klasifikace čistoty vzduchu.

5. Vyhláška Ministerstva zdravotnictví ČR č. 252/2004 Sb., kterou se stanoví hygienické požadavky na pitnou a teplou vodu a četnost a rozsah kontroly pitné vody, ve znění vyhl. č. 187/2005 Sb. a vyhl.č. 293/2006 Sb.

6. Anaissie EJ, Peznak SC, Dignani C. The hospital water supply as a source of nosocomial infection. Arch Intern Med 2002; 162: 1483-92.

7. Rutala WA, Webber DJ. Water as a reservoir of nosocomial pathogens. Infect Control Hosp Epidemiol 1997; 18: 609-16.

8. Perola O, Nousiainen T, Suomalainen S, Aukee S, Karkkainen UM, Kauppinen J, Ojanen T, Katila ML. Recurrent Sphingomonas paucimobilis - bacteraemia associated with a multi-bacterial water-borne epidemic among neutropenic patients. J Hosp Infect 2002; 50: 196-201.

9. Warris A, Gaustad P, Meis JFGM, Voss A, Verweij PE, Abrahamsen TG. Recovery of filamentous fungi from water in a paediatric bone marrow transplantation unit. J Hosp Infect 2001; 47: 143-8.

10. Anaissie EJ, Costa SF. Nosocomial aspergillosis is waterborne. Clin Infect Dis 2001; 33: 1546-8.

11. Anaissie EJ, Stratton SL, Dignani MC, Summerbell RC, RexJH, Monson TP, Spencer T, Kasai M, Francesconi A, Walsh TJ. Pathogenic Aspergillus species recovered from a hospital water system: A 3year prospective study. Clin Infect Dis 2002; 34: 780-9.

12. Anaissie EJ, Kuchar RT, Rex JH, et al. Fusariosis associated with path ogenic Fusarium species colonization of hospital water system: a new paradigm for epidemiology of opportunistic mold infections. Clin Infect Dis 2001; 33: 1871-8.

13. Miyamoto M, Yamaguchi Y, Sasatsu M. Disinfectant effects of hot water, ultraviolet light, silver ions and chlorine on strains of Legionella and nontuberculous mycobacteria. Microbios 2000; 101: 7-13.

14. Hall J, Hodgson G, Kerr KG. Provision of safe potable water for immunocompromised patients in hospital. J Hosp Infect 2004; 58 : 155-8.

15. Halabi M, Wiesholtzer-Pittl M, Schoberl J, Mittermayer H. Non-touch fittings in hospitals: a possible source of Pseudomonas aeruginosa and Legionella spp. J Hosp Infect 2001; 49: 117-21.

16. Sullivan KM, Dykewicz CA, Longworth DL, Boeckh M, Baden LR, Rubin RH, Sepkowitz KA. Preventing opportunistic infections after hematopoietic stem cell transplantation: The Centers for Disease
Control and Prevention, Infectious Diseases Society of America, and American Society for Blood and Marrow Transplantation Practice Guidelines and Beyond. Hematology 2001: 392-421.

17. Berrouane YF, McNutt LA, Buschelman BJ, Rhomberg PR, Sanford MD, Hollis RJ, Pfaller MA, Herwaldt LA. Outbreak of severe Pseudomonas aeruginosa infections caused by a contaminated drain in a whirlpool bathttub. Clin Infect Dis 2000; 31: 1331-7.

18. Verweij PE, Bijl D, Melchers WJ, De Pauw BE, Meis JF, HoogkampKorstanje JA, Voss A. Pseudo-outbreak of multiresistant Pseudomonas aeruginosa in a hematology unit. Infect Control Hosp Epidemiol 1997; 18: $128-31$.

19. Geshwiler M. HVAC Design Manual for Hospitals and Clinics. ASHRAE, Atlanta 2003; ISBN 1-931862-26-5, 16: 33-8.

20. Centers for Disease Control and Prevention. Guidelines for environmental infection control in health-care facilities: recommendations of CDC and the Healthcare Infection Control PracticesAdvisory Committee (HICPAC). MMWR 2003;52(No. RR-10).

21. Maroni M. Ventilation and Indoor Air Quality in Hospitals. Kluwer Academic Publishers, Dordrecht - Boston - London: 1996.

22. Trexler PC, Reynolds LI. Flexibile Film Apparatus for the Rearing and Use of Germfree Animals. Applied Microbiology 1957; 5: 406.

23. Schwartz SA, Perry S. Patient protection in cancer chemoterapy. JAMA 1966; 197: 105-9.

24. James KW, Jameson B, Kay HE, Lynch J, Ngan H. Some practical aspects of intensive cytotoxic therapy. Lancet 1967; 1: 1045-9.

25. Schneider M, Schwarzenberg L, Amiel JL, et al. Pathogen-free Isolation Unit-Three Years' Experience. Brit med J 1969; 1: 836-9.

26. Bodey GP, Freireich EJ, Frei E III. Studies of patients in a laminar air flow unit. Cancer 1969; 24: 972-80.

27. Bláha $M$, Měrka V. Podpůrná léčba útlumů krvetvorby. 1. vyd. Naševojsko. Kapitola Prevence infekčních komplikací, Praha 1986; 205-89.

28. Bagshawe KD. Ultra-clean ward for cancer chemotherapy. Brit Med 1964; 2: 871-3.

29. Dykewicz CA. Hospital infection control in hematopoietic stem cell transplant recipients. Emerg Infect Dis 2001; 7: 263-7.

30. Měrka V. Úloha dezinfekce a antisepse v prevenci nejdůležitějších nozokomiálních nákaz, systémy s obrácenou izolací. In: Nozokomiální nákazy. Šrámová et al. Maxdorff Jessenius, Praha 1995; 163-89.

31. Streifel AJ. Maintenance and engineering. In: Association for Professionals in Infection Control and Epidemiology, Inc. Infection control and applied epidemiology: principles and practice. 2nd edition. Mosby, St. Louis 2000; 71-6.

32. Mackall C, Fry T, Gress R, Peggs K, Storek J, Toubert A. Background to hematopoietic cell transplantation, including post transplant immune recovery. Bone Marrow Transplant 2009; 44: 457-62.

33. Tomblyn M, Chiller T, Einsele H, et al. Guidelines for preventing infectious complications among hematopoietic cell transplantation recipients: a global perspective. Biol Blood Marrow Transplant 2009; 15: 1143-238.

\section{Address for correspondence}

\section{Ondřej Holý}

Department of Preventive Medicine

Faculty of Medicine and Dentistry

Palacký University Olomouc

Hněvotínská 375/15

77515 Olomouc

Czech Republic

fax +420585632668

tel. +420777105081

e-mail: holy.ondrej@seznam.cz

Submitted: $\quad 25.03 .2011$

Accepted: $\quad 18.01 .2012$ 